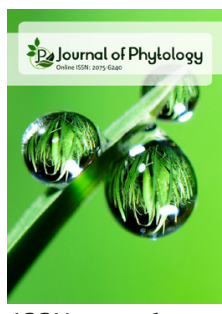

ISSN: $2075-6240$

Received: August 012020 Revised: September 182020 Accepted: September 212020 Published: Sepember 262020

*Corresponding Author: S. Kalaiselvi Email: kalaiselvi_bc@avinuty. ac.in

\section{Impact of soaking, sprouting on antioxidant and anti-nutritional factors in milletgrains}

\author{
G. Bhuvaneshwari', A. Nirmalakumari², S. Kalaiselvi ${ }^{{ }^{*}}$ \\ 'Department of Biochemistry, Biotechnology, and Bioinformatics, Avinashilingam Institute for Home Science and \\ Higher Education for women, Coimbatore-641043, Tamilnadu, India, ${ }^{2}$ Centre of Excellence in Millets, Athiyanthal, \\ Thiruvannamalai, Tamil Nadu Agricultural University, Coimbatore- 641003, Tamilnadu, India
}

\begin{abstract}
Commonly consumed millet types viz., Little millet, foxtail millet, pearl millet, finger millet, and Kodo millet were tested under two processing methods of soaking and germination at a different time point. Most popular processing practices adopted by Indian households were studied for their influence on the biochemical properties, antioxidant profile, and anti-nutritive factors. The results showed that the sprouting process showed a maximum influence on the antioxidant and anti-nutritive factors. The comparative analysis of the five millets suggested 24h soaking and 24h germination was found to be best for producing nutritionally enriched millet products. Tannin content decreases with an increase in germination. The reduction in tannin was about $50 \%$ in little millet $(0.347 \mathrm{mg} / \mathrm{g})$ and the highest was recorded in finger millet $(2.07 \mathrm{mg} / \mathrm{g})$. The highest amount of saponin content was found in pearl millet $(39.53 \mathrm{mg} / \mathrm{g})$ followed by finger millet $(34.86 \mathrm{mg} / \mathrm{g}$ ) with $24 \mathrm{hr}$ soaking and $24 \mathrm{hr}$ germination. The phytase activity was found to be higher in little millet $(61.520 \mathrm{u} / \mathrm{kg}$ ) when prolonged soaking and germination. The DPPH assay showed sprouted foxtail millet grains contain more antioxidant activity (81.13\%) with extended period of soaking and germination.
\end{abstract}

KEYWORDS: Millets, tannin, saponin, phytase, antioxidants

\section{INTRODUCTION}

Millets are also considered to be a rich source of carbohydrates, phytochemicals, and also for other micronutrients like iron and zinc [1]. Especially millets are preferred for its malting quality which inturn enhances the bioavailability of the nutrients and also improves the nutritional quality. The amino acid constitution of the millet protein isa good source for methionine except for lysine and threonine. The availability of iron content in millets is high but the rate of bioavailability is less due to the presence of phenol fraction in the bran. Effective iron utilization in millets can be withheld by practicing traditional household processing techniques such as threshing, dry milling, dehulling, cleaning, soaking, germination which could reduce the effect of inhibitors [2]. These practices also decrease the effect of undesirable compounds, which increases the acceptability and nutritional quality [3]. Recently, processing, nutritional composition and health benefits of finger millet was studied and revealed that the process of pre soaking and germinating increases the dietetic and sensory properties of finger millet and equally reduces the anti nutritional and inhibitory activity of phenol, tannin and phytic acid [4]. In order to improve the bioavailability of the minerals, soaking is the best practice for popular food preparation which reduces the anti- nutritional factors such as phytic acid. The whole and dehulled seeds and flours of the millets were studied for its iron and zinc concentration and also for the degradation and leaching of phytate compounds after soaking for certain hours. The results revealed that the dehulled and milled millet grains before soaking facilitates leaching of phytates and phytases and hence phytate degradation happens. Germination is one of the processes practiced in legumes and cereals to increase their palatability and nutritional value via the breakdown of antinutrients such as phytate and protease inhibitors. Nutritionalcontent and functionality of millet grains nutrients were widely studied [5]. Many of the malted millet foods the grains are germinated and dried which leads to a lot of biochemical changes in nutrient composition. The grain nutrient analysis will give better information on the process of germination of seeds. Hence the present study was taken up to analyze antioxidant and anti-nutritive factors during the process of seed soaking followed by sprouting in popular millets viz., pearl millet, foxtail millet, little millet, Kodo millet, and finger millet

\section{MATERIALS AND METHODS}

The Pearl millet (CO 9), Kodo millet (CO (VK)2), Finger millet, Little millet (ALTl), and Foxtail millet ( ALT1) were

Copyright: $\odot$ The authors. This article is open access and licensed under the terms of the Creative Commons Attribution License (http://creativecommons.org/licenses/by/4.0/) which permits unrestricted, use, distribution and reproduction in any medium, or format for any purpose, even commercially provided the work is properly cited. Attribution - You must give appropriate credit, provide a link to the license, and indicate if changes were made. 
collected from Centre of Excellence, Millets, Athiyanthal, TNAU, Tiruvannamalai. All the grains were dehusked without any thermal or chemical treatment and were stored inan airtight container at room temperature. All the millet samples of $10 \mathrm{~g}$ soaked in $50 \mathrm{ml}$ distilled water. The soaking for two time periods (12h and 24h), germinated and harvested for two time periods (12h, 24h). Dried, powdered samples were stored in airtight containers and used for analysis. The antioxidant activityand anti-nutritive factors were analyzed in different millets and at different time points. The amount of respective biochemical constituent is expressed in $\mathrm{mg} / \mathrm{g}$ of sample. The non-enzymatic antioxidant assay of total phenols [6-10], DPPH assay, Tannin estimation, and phytate enzyme assay [11] were analyzed in the samples at different time points of soaking and germination. The experiments are carried out in a Completely Randomized Design (CRD). The data were analyzed by a two-way ANOVA table and the difference existed between the mean values are compared at the level of $\mathrm{P} \leq 0.05$ through AgRes software.

\section{RESULTS AND DISCUSSION}

Millets are generally poor in digestibility and low bioavailability of minerals due to the presence of heritable anti-nutritional factors [12]. Processing operation reduces the anti-nutritional factors but increases the loss of micronutrients which are of major concern. Techniques like mechanical, thermal, or biological processes can improve the nutritional availability in foods $[13,14]$. Wet processing such as soaking germination and fermentation tends to reduce the phytic acid and increases the solubility of the minerals and thus enhances the bioavailability of minerals in cereals and legumes [15]. Processing value of millets in product development has a promising prospect with respect to the nutrition, quality, and health benefits which can be an alternate source to cereals but the scope and utilization are yet to be established [5].

The household processing technique such as pre-soaking and germination etc. are the best tool to enhance the level of nutrition content of food stuffs. Among many techniques, pre soaking and germination are the biochemical enrichment tool where it increases the bioavailability of minerals through transition of a seed from its dormant to vital active state which improves the nutritive level of seeds. Also reduces the antinutrients viz., oxalic acid, phytic acid, trypsin inhibitor and tannin as well as increases the optimum level of absorbable nutrients [16,17]. Thus in this present study, the influence of soaking and germination on biochemical constituents suchasenzymic and non-enzymic antioxidants, and anti-nutritive factors were investigated in the Little millet, foxtail millet, pearl millet, finger millet, and Kodo millet. The grains were soaked and germinated for different time intervals (Figure 1). Then the grains from each treatment were dried, powdered, and used for assessment of certain biochemical, antioxidant, and anti-nutritive factors.

The ash content has several variations in which $12 \mathrm{~h}$ soaking $24 \mathrm{~h}$ germinated millets showed loss of minerals by low ash content, whereas $24 \mathrm{~h}$ soaking $24 \mathrm{~h}$ germinated millets has a considerably high level of ash content, which is due to a decreased level of crude fat and carbohydrate. Moisture content increases with an increase in germination. When compared to other millets finger millet possesses the highest amount of moisture content. It is found that the moisture content of the seeds during germination is increased which means it absorbs water from soaking medium for the metabolism to initiate the immobilisation of amylase to the embryonic region which affects the structure of grain.

\section{CHANGES IN LEVELS OF ENZYMIC ANTIOXIDANT}

DPPH assay was conducted to analyze the changes in levels of enzymic antioxidants in selected millet. Both raw and sprouted millets contain enzymic antioxidant activity, in which foxtail millet was noted to have the highest amount ranging from $62.833 \pm 0.289 \%$ in $\mathrm{Tl}$ to $81.123 \pm 0.125 \%$ in $\mathrm{T} 7$, this is followed by finger millet, little millet, kodo millet and pearl millet (Table 1).

There is an increase in the antioxidant level in all control and treated millets. From table lit is clear that among control, pearl

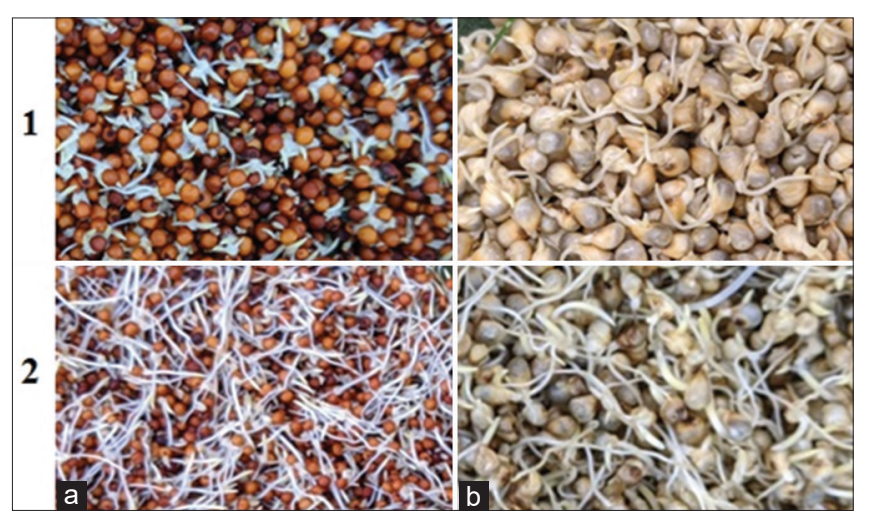

Figure 1: Soaking and Germination of Finger millet (a) and Pearl millet (b). Treatment for $12 \mathrm{hrs}$ (1) and $24 \mathrm{hrs}(2)$

Table 1: Influence of soaking and germination time on DPPH content of the selected millets

\begin{tabular}{lccccc}
\hline Treatment & \multicolumn{5}{c}{ DPPH activity (\%) } \\
\cline { 2 - 6 } & M1(1) & M2 (2) & M3 (3) & M4 (4) & M5 (5) \\
\hline T1 & $28.077 \pm 0.067$ & $62.833 \pm 0.289$ & $56.713 \pm 1.027$ & $34.123 \pm 0.214$ & $36.863 \pm 0.228$ \\
T2 & $34.203 \pm 0.188$ & $66.170 \pm 0.652$ & $58.457 \pm 0.791$ & $36.800 \pm 0.755$ & $37.203 \pm 0.263$ \\
T3 & $42.913 \pm 0.878$ & $70.917 \pm 0.936$ & $63.133 \pm 0.709$ & $42.873 \pm 0.860$ & $40.440 \pm 0.383$ \\
T4 & $41.173 \pm 0.657$ & $67.913 \pm 0.878$ & $65.247 \pm 0.329$ & $40.407 \pm 0.352$ & $43.550 \pm 0.482$ \\
T5 & $50.333 \pm 0.577$ & $75.740 \pm 4.019$ & $68.153 \pm 0.172$ & $50.040 \pm 0.069$ & $53.080 \pm 0.069$ \\
T6 & $50.707 \pm 0.615$ & $81.813 \pm 0.497$ & $68.250 \pm 0.433$ & $50.300 \pm 0.520$ & $50.040 \pm 0.069$ \\
T7 & $55.550 \pm 0.638$ & $81.123 \pm 0.125$ & $78.340 \pm 0.489$ & $56.167 \pm 0.144$ & $62.433 \pm 0.451$ \\
\hline
\end{tabular}

(1) Finger millet; (2) Foxtail millet; (3)Kodo millet; (4) Little millet; (5) Pearl millet 
millet $(24.863 \pm 0.228 \mathrm{mg} / \mathrm{g})$ has the lowest range, whereas, among treatments, finger millet $\mathrm{T} 2$ has the lowest range of enzymic antioxidant activity. The reducing ability of a substance may explain its potential antioxidant activity $[18,19]$. The result from this present study showed that foxtail and Kodo millet possess the ability to scavenge free radicals and therefore can be employed as a source of antioxidant to prevent the accumulation of unwanted substances in the system [20].

From the treatments studied $\mathrm{T} 7$ recorded the highest antioxidant activity in all the millets. A similar study reported that the DPPH scavenging ability of the foxtail millet increased from 35.44 to $63.07 \mathrm{mM}$ trolox $/ \mathrm{g}$ at the time of germination may be due to increased concentration of hexadecanoic acid methyl ester; 9,12-Octadecadienoic acid ethyl ester and synthesis of new polyphenolic compounds like pentadecanoic acid; 14-methyl methyl ester; 9,12,150ctadecatrienoic acid.During germination some bound components might have liberated and played a role in DPPH and hydrogen peroxide scavenging when the endosperm has modified by the hydrolytic enzymes [21]. Similar results are in accordance with [22].

\section{SAPONIN CHANGES IN MILLETS}

In the present study, pearl millet recorded the highest amount of saponin followed by foxtail millet, little millet, finger millet, and kodo millet. Increment of saponin content ranged from $29.117 \pm 0.732$ to $39.530 \pm 0.148 \mathrm{mg} / \mathrm{g}$ in pearl millet and $24.730 \pm 0.204$ to $34.860 \pm 0.079 \mathrm{mg} / \mathrm{g}$ in finger millet flour. This result may be due to the displacement of stored phytochemicals from the sprouts. Similarly from the other studies, saponin content was increased from 18.01 to $31.91 \mathrm{mg} / \mathrm{g}$ in finger millet [23]. Saponin is useful for the human physiological system and also for treating various diseases. Decreased in overall blood cholesterol is associated with the indigestion status of saponin. The abundant nature of phytochemicals in the millets increases the nutraceutical potentials, thus making them a reliable source of functional food [24].

Among treatments, it was observed that T7 (24h soaking 24h germination) has the highest range followed by $\mathrm{T} 5$ (24h soaking $12 \mathrm{~h}$ germination) and T6 (12h soaking $24 \mathrm{~h}$ germination), T4 (12h soaking $12 \mathrm{~h}$ germination), T3 (24h soaking), T2 (12h soaking), Tl (control). When grains or seeds are hydrated (soaked) and then held (sprouted) under ambient conditions, both endogenous and newly synthesizing enzymes begin to modify seeds and increases the phytochemical constituents present in the millets. This is one of the reasons why the saponin content is high during germination than other treatments [25].

From the graph given below (Figure 2), it is clear that millet 5 with treatment 7 (Pearl millet with 24h soaking 24h germination) shows the best performance which may be due to the activation of the endogenous enzyme in pearl millet. This is followed by M5T6, M5T4, M5T5, M5T3, M1T7. Next to pearl millet, finger millet with $24 \mathrm{~h}$ soaking and $24 \mathrm{~h}$ germination has a high amount of saponin. Among all the treatments, T7 has the best performing

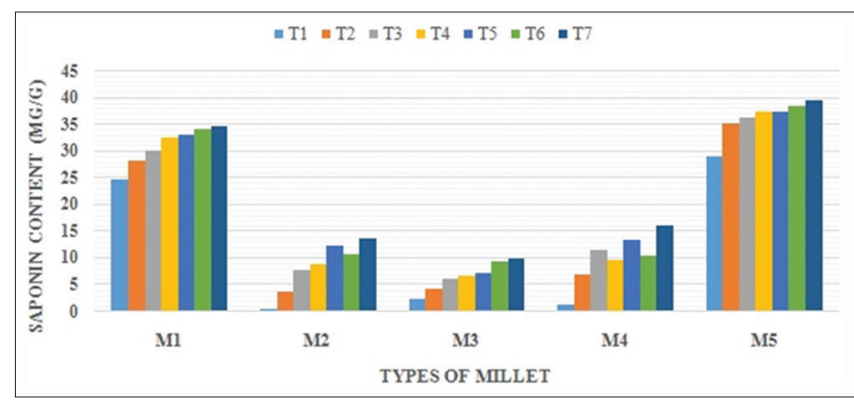

Figure 2: Influence of soaking and germination time in saponin content of five millets $(\mathrm{mg} / \mathrm{g})$

(T1) Control, (T2) $12 \mathrm{hr}$ soaking, (T3) $24 \mathrm{hr}$ soaking, (T4) $12 \mathrm{hr}$ soaking and $12 \mathrm{hr}$ germination, (T5) $24 \mathrm{hr}$ soaking and $12 \mathrm{hr}$ germination, (T6) $12 \mathrm{hr}$ soaking and $24 \mathrm{hr}$ germination, (T7) $24 \mathrm{hr}$ soaking and $24 \mathrm{hr}$ germination , (M1) Finger millet, (M2) Foxtail millet (M3) Kodo millet, (M4) Little millet and (M5) Pearl millet.

treatment with the highest amount of saponin content and pearl millet has a high amount of saponin among other millets

\section{DETERMINATION OF TANNIN}

The tannin content recorded from all the millets is presented in Table 2. The tannin content was low in little millet ranged between $1.223 \pm 0.021 \mathrm{mg} / \mathrm{g}$ in $\mathrm{Tl}$ to $0.347 \pm 0.045 \mathrm{mg} / \mathrm{g}$ in T7. The reduction in tannin was about $50 \%$ in little millet. This reduction is mainly due to leaching [26]. In general, tannin affects the digestive tract and its metabolism also toxic which may be recovered through the process of germination which reduces the tannin level in millet flours and indirectly reduces the negative effect of tannin [27]. Tannin content reduces when there is an increase in the germination period. The highest range of tannin was found in finger millet (ranging from $2.077 \pm 0.068 \mathrm{mg} / \mathrm{g}$ to $0.553 \pm 0.050 \mathrm{mg} / \mathrm{g}$ ) followed by foxtail millet, pearl millet, and Kodomillet.Among treatments, T7 and T5 are found to have the lowest amount of tannin content in all the millets. So, from this, we say that $24 \mathrm{~h}$ soaking with a difference of germination period influences the tannin content. A similar study was observed in which the tannin is reduced to $50 \%$ [28]. A decrease in anti-nutritional factors during germination could lead to leaching of polyphenols in the soaking water [29] and increased enzymatic treatment during germination [30]. In comparison with all treated millets, we found that M4T7 $(0.347 \pm 0.045 \mathrm{mg} / \mathrm{g})$ has the lowest amount of tannin and MlTl $(2.077 \pm 0.068 \mathrm{mg} / \mathrm{g})$ has the highest amount.

\section{PHYTASE ASSAY}

Phytase activity of both raw and sprouted millets are shown in Figure 3. Phytase activity was found to be high in Kodo millet ranging from $54.413 \pm 0.454$ unit $/ \mathrm{kg}$ in $\mathrm{Tl}$ to $60.627 \pm 0.335 \mathrm{unit} / \mathrm{kg}$ in $\mathrm{T} 7$, which is followed by little millet, finger millet, foxtail millet, and pearl millet.

Germination showed a significant increase in the phytase activity of all the samples studied. This may be due to the de nova synthesis of the enzyme at the time of germination [31]. The lowest level of phytase was observed in pearl millet ranging 
Table 2: Influence of soaking and germination time on the tannin content of the selected millets

\begin{tabular}{|c|c|c|c|c|c|}
\hline \multirow[t]{2}{*}{ Treatment } & \multicolumn{5}{|c|}{ Tannin content $(\mathrm{mg} / \mathrm{g})$} \\
\hline & Ml (1) & M2 (2) & M3 (3) & M4 (4) & M5 (5) \\
\hline $\mathrm{T1}$ & $2.077 \pm 0.068$ & $1.971 \pm 0.038$ & $1.420 \pm 0.026$ & $1.223 \pm 0.021$ & $1.863 \pm 0.107$ \\
\hline $\mathrm{T} 2$ & $1.620 \pm 0.026$ & $1.830 \pm 0.036$ & $1.247 \pm 0.045$ & $0.973 \pm 0.021$ & $1.360 \pm 0.114$ \\
\hline T3 & $1.220 \pm 0.035$ & $1.627 \pm 0.025$ & $0.930 \pm 0.053$ & $0.733 \pm 0.040$ & $0.897 \pm 0.090$ \\
\hline T4 & $1.473 \pm 0.071$ & $1.623 \pm 0.021$ & $0.967 \pm 0.021$ & $0.740 \pm 0.040$ & $0.900 \pm 0.079$ \\
\hline T5 & $0.763 \pm 0.015$ & $1.433 \pm 0.021$ & $0.780 \pm 0.010$ & $0.550 \pm 0.046$ & $0.733 \pm 0.042$ \\
\hline T6 & $1.253 \pm 0.015$ & $1.410 \pm 0.000$ & $0.753 \pm 0.031$ & $0.533 \pm 0.031$ & $0.783 \pm 0.025$ \\
\hline T7 & $0.553 \pm 0.050$ & $1.233 \pm 0.042$ & $0.527 \pm 0.031$ & $0.347 \pm 0.045$ & $0.537 \pm 0.032$ \\
\hline
\end{tabular}

(1) Finger millet; (2) Foxtail millet; (3) Kodo millet; (4) Little millet; (5) Pearl millet

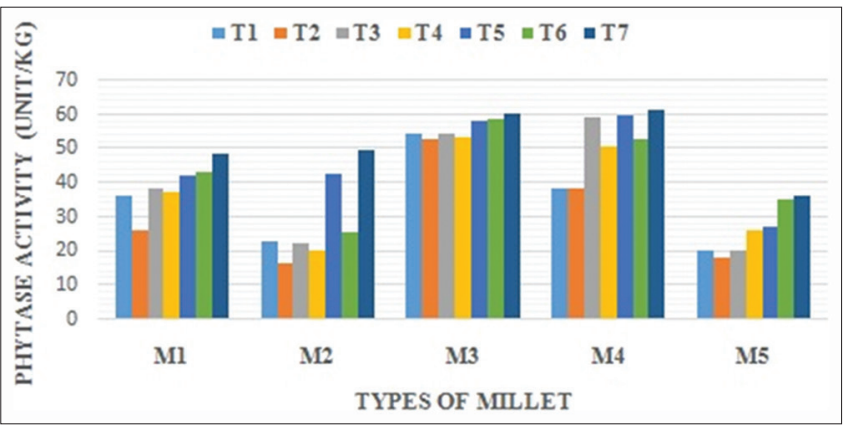

Figure 3: Influence of soaking and germination time on phytase activity (unit/kg)

(T1) Control, (T2) $12 \mathrm{hr}$ soaking, (T3) $24 \mathrm{hr}$ soaking, (T4) $12 \mathrm{hr}$ soaking and $12 \mathrm{hr}$ germination, (T5) $24 \mathrm{hr}$ soaking and $12 \mathrm{hr}$ germination, (T6) $12 \mathrm{hr}$ soaking and $24 \mathrm{hr}$ germination, (T7) $24 \mathrm{hr}$ soaking and $24 \mathrm{hr}$ germination, (M1) Finger millet, (M2) Foxtail millet (M3)Kodo millet, (M4) Little millet and (M5) Pearl millet.

from $20.420 \pm 0.365 \mathrm{u} / \mathrm{kg}$ in $\mathrm{Tl}$ to $36.430 \pm 0.373 \mathrm{u} / \mathrm{kg}$. Phytase activity was highest on $\mathrm{T} 7$ and $\mathrm{T} 5$ respectively due to prolonged soaking. Whereas the phytate level decreases with an increase in germination due to the hydrolysis of phytate to phosphate and myoinositol phosphate [27]. In our study, we found that germination after soaking increases the level of phytase activity in all treated millets. From this study, it is clear that the bounded inorganic phosphorous has been liberated in a high amount during soaking and germination. Results showed that the increased level of phytase activity was accompanied by decreased antinutrient, phytate, and slightly increase phosphorous. Thus the increase in phytase activity and decrease in phytate content are expected to improve phosphorous availability and utilization which would reduce the phosphorous pollution [32].

From this study, we observed that ash content has several variations in which $12 \mathrm{~h}$ soaking $24 \mathrm{~h}$ germinated millets showed loss of minerals by low ash content, whereas $24 \mathrm{~h}$ soaking $24 \mathrm{~h}$ germinated millets havea considerably high level of ash content, which is due to a decreased level of crude fat and carbohydrate. Moisture content increases with an increase in germination. The highest moisture content was recorded in finger millet when compare to other millets studied. Marked level of increase in moisture content was noticed at the time of germination which may be directly proportional to the fact that the grain absorbs moisture from the soaking medium for its metabolism and reflects on the grain structure. As the time of soaking increases, more number of cells in the seeds are hydrated.
The differential period of soaking and germination resulted in a change of saponin content. The level of saponin was found to be high in the T7 of pearl millet when compared with others. Significantly much difference was not observed among $24 \mathrm{~h}$ soaking and $24 \mathrm{~h}$ germination period for tannin content. Upon soaking and germination the phytase activity was found to increase when compared with control. Kodo millet was found to have a high amount of phytase activity. The raw and sprouted millets of foxtail have reported being high, the highest flavonoid content was observed in T7 and lowest in pearl millet. DPPH assay was carried out, in which foxtail millet is found to have a high amount of antioxidant activity and pearl millet has a low amount.

\section{FUNDING}

The financial support by DST-CURIE for the Department of Biochemistry, Biotechnology and Bioinformatics, Avinashilingam Institute for Home Science and Higher Education for Women, Coimbatore is gratefully acknowledged.

\section{REFERENCES}

1. Mal B, Padulosi S, Ravi, SB, 2010. Minor millets in South Asia: learnings from IFAD-NUS Project in India and Nepal. Bioversity InternationalMaccarese, Rome, Italy and the MS Swaminathan Research Foundation, Chennai, India, 185.

2. Begum JM. Refined processing and Products for commercial use and health benefits from finger millet. In: KrishneGowda KT and Seetharam A (Eds.), Food Uses of Small Millets and Avenues for Further Processing and Value Addition, Project Coordination Cell, All India Coordinated Small Millets Improvement Project, ICAR, UAS, GKVK, Banglore, India. 2016.

3. Pradeep PM, Sreerama YN. Impact of processing on the phenolic profiles of small millets: Evaluation of their antioxidant and enzyme inhibitory properties associated with hyperglycemia. Food chemistry. 2015; 169:455-463.

4. Ramashia SE, Anyasi TA, Gwata ET, Meddows-Taylor S, Jideani Al. Processing, nutritional composition and health benefits of finger millet in sub-saharan Africa. Food Science and Technology. 2019;39:253-66.

5. Jaybhaye RV, Pardeshi IL, Vengaiah PC, Srivastav PP. Processing and technology for millet based food products: a review. Journal of Ready to Eat Food. 2014; 2:32-48.

6. Roe JH. Appraisal of methods for the determination of L-ascorbic acid. Annals of the New York Academy of Sciences. 1961; 92:277.

7. Malik CP, Singh MB. In: Plant Enzymology and Histo- Enzymology. Kalyani Publications, New Delhi.1980

8. Zhishen J, Mengcheng T, Jianming W. The determination of flavonoid contents in mulberry and their scavenging effects on superoxide radicals. Food Chemistry. 1999; 64:555-559.

9. Harborne JB. Phytochemical Methods London Chapman and Hall, Ltd. 1973; 49-188. 
10. Baccou JC, Lambert F and Sauvaire Y. Spectrophotometric method for the determination of total steroidal sapogenin. Analyst. 1977; 1215: 458-465.

11. Eeckhout W, M. de Paepe. Total phosphorus, phytate-phosphorus and phytase activity in plant feedstuffs. Animal Feed Science and Technology. 1994;47:19-29.

12. Nehir El S, Simsek S. Food technological applications for optimal nutrition: an overview of opportunities for the food industry. Comprehensive Reviews in Food Science and Food Safety, 2013;1:2-12.

13. Kayode APP, Hounhouigan JD, Nout MJR. Impact of brewing process operations on phytate, phenolic compounds and in vitro solubility of iron and zinc in opaque sorghum beer. LWT-Food Science and Technology. 2007; 5: 834-841.

14. Steiner T, Mosenthin R, Zimmermann B, Greiner R, Roth S. Distribution of total phosphorus, phytate phosphorus and phytase activity in legume seeds, cereals and cereal by-products as influenced by harvest year and cultivar, Animal Feed Science and Technology. 2007; 133:320-334

15. Afify AEMM, El-Beltagi HS, El-Salam SMA, Omran AA. Bioavailability of iron, zinc, phytate and phytase activity during soaking and germination of white sorghum varieties. Plos one. 2011;10: e25512.

16. Inyang CU, Zakari UM. Effect of germination and fermentation of pearl millet on proximate, chemical and sensory properties of instant "Fura"-a Nigerian cereal food. Pakistan Journal of Nutrition. 2008;7:9-12.

17. Ghavidel RA, Prakash J. The impact of germination and dehulling on nutrients, antinutrients, in vitro iron and calcium bioavailability and in vitro starch and protein digestibility of some legume seeds. LWT-Food Science and Technology. 2007;40:1292-1299.

18. Adesegun SA, Elechi NA, Coker HA. Antioxidant activities of methanolic extract of Sapiumellipticum. Pakistan journal of biological sciences: 2008;3:453.

19. Sofidiya MO, Odukoya OA, Familoni OB, Inya-Agha SI. Free radical scavenging activity of some Nigerian medicinal plants. PlantaMedica. 2006; 11:171.

20. Odusola KB, Ilesanmi FF, Akinloye OA. Assessment of nutritional composition and antioxidant ability of pearl millet (Pennisetumglaucum). American Journal of Research Communication. 2013;6:262-72.

21. Doblado R, Frias J, Vidal-Valverde C (2007). Changes in vitamin C content and antioxidant capacity of raw and germinated cowpea (Vignasinensis var. Carilla) seeds induced by high pressure treatment. Food Chemistry. 1985;101:918-923.
22. Hafez R, Fouad A. Mitigation of Genotoxic and Cytotoxic Effects of Silver Nanoparticles on Onion Root Tips using some Antioxidant Scavengers. Egyptian Journal of Botany. 2020; 1:133-45.

23. Rupasinghe HV, Jackson CJC, Poysa V, Di Berardo C, Bewley JD, Jenkinson J. Soyasapogenol A and B distribution in soybean (Glycine max L. Merr.) in relation to seed physiology, genetic variability, and growing location. Journal of Agricultural and Food Chemistry.2003; 20: 5888-5894.

24. Owheruo JO, Ifesan BO, Kolawole AO. Physicochemical properties of malted finger millet (Eleusinecoracana) and pearl millet (Pennisetumglaucum). Food science \& nutrition. 2019;2:476-482.

25. Taylor JR, Duodu K.G. Effects of processing sorghum and millets on their phenolic phytochemicals and the implications of this to the health-enhancing properties of sorghum and millet food and beverage products. Journal of the Science of Food and Agriculture. 2015; 2:225-237.

26. Ogunlakin GO, Oke MO, Babarinde GO and Olatunbosu DG. Effect of drying methods on proximate composition and physico-chemical properties of cocoyam flour. American Journal of Food Technology. 2012; 7: 245-250.

27. Nithya KS, Ramachandramurty B, Krishnamoorthy VV. Effect of processing methods on nutritional and anti-nutritional qualities of hybrid (COHCU-8) and traditional (CO7) pearl millet varieties of India. Journal of Biological Science. 2007;7:643-647.

28. Abioye VF, Ogunlakin GO, Taiwo G. Effect of germination on antioxidant activity, total phenols, flavonoids and anti-nutritional content of finger millet flour. Journal of Food Processing \& Technology. 2018:9:719.

29. Jood S, Chauhan MB, Kapoor CA. Polyphenols of chickpea and black gram as affected by domastic processing and cooking methods. Journal of Science and Food Agriculture. 1987; 39:145-149.

30. Bishnoi S, Khetarpaul N, Yadav RK.. Effect of domestic processing and cooking methods on phytic acid and polyphenol conents of pea cultiva. Plant Food for Human Nutrition. 1994; 47:381-388

31. Sung HG, Shin HT, Ha JK, Lai HL, Cheng KJ, Lee JH. Effect of GerminationTemperature on Characteristics of Phytase Production from Barley.Bioresource Technology.2005; 11: 1297-1303.

32. Azeke MA, Egielewa SJ, Eigbogbo MU, Ihimire IG. Effect of germination on the phytase activity, phytate and total phosphorus contents of rice (Oryzasativa), maize (Zea mays), millet (Panicummiliaceum), sorghum (Sorghum bicolor) and wheat (Triticumaestivum). Journal of food science and technology. 2011;6:724-729. 